\title{
Pengaruh Step down Protein dan Penambahan Acidifier pada Pakan terhadap Performans Ayam Broiler
}

\section{Effect of Step down Protein and Addition Acidifier of Feed on Broiler Chickens Performance}

\author{
S. Huda ${ }^{1}$, L. D. Mahfudz ${ }^{2}$ dan S. Kismiati ${ }^{2}$ \\ Fakultas Peternakan dan Pertanian, Universitas Diponegoro \\ Kampus drh. R. Soedjono Koesoemowardjojo Tembalang, Semarang 50275 \\ *Corresponding author : syaifulhuda2013@gmail.com
}

\begin{abstract}
The research was purposed to study the effect of step down protein at in various levels and provisions of acidifier on feed consumption, body weight gain, and feed convertion. The materials used were 210 day old broiler Chickens (DOC) unsexed with an average body weight of $44.34 \pm 0.14 \mathrm{~kg}$ and the rations with different protein levels. The experimental design used was 3 treatments and 7 repeatations, so there were 21 experiment units with 10 chickens per unit. The treatments applied were step down protein with levels of $22 \%, 18 \%$ and $16 \%$ and provisions $1.2 \%$ of acidifier. The parameter used in this study were the feed consumption, body weight gain, and feed convertion. The results of this study showed the significant effects $(\mathrm{P}<0.05)$ were found on the decreased of feed consumption and body weight gain and significant effect $(\mathrm{P}<0.05)$ was found on increase of feed convertion. The conclusion from this study was the step down protein $4 \%$ and $6 \%$ with the addition of $1.2 \%$ acidifier / 100 grams of feed was not able to increase the best performance for broiler chickens.
\end{abstract}

Key words : broiler chicken, step down protein, acidifier, performance.

\begin{abstract}
ABSTRAK
Penelitian ini bertujuan untuk mengetahui pengaruh level step down dengan pemberian acidifier pada berbagai protein pakan terhadap konsumsi pakan, pertambahan bobot badan dan konversi pakan. Penelitian ini menggunakan 210 Day Old Chicken (DOC) Unsexed dengan rata-rata bobot badan 44,34 $\pm 0,14 \mathrm{~g}$ dan pakan dengan level protein yang berbeda. Rancangan yang digunakan adalah rancangan acak lengkap dengan 3 perlakuan dan 7 ulangan, sehingga ada 21 unit percobaan dengan jumlah 10 ekor ayam tiap unit. Perlakuan yang diterapkan yaitu step down protein dengan level 22\%, 18\% dan 16\% dengan pemberian acidifier 1,2\%/100 gram pakan. Parameter yang diamati penelitian ini adalah konsumsi pakan, pertambahan bobot badan dan konversi pakan. Hasil penelitian menunjukkan penurunan kadar protein pakan (stepdown protein) $4-6 \%$ dengan penambahan acidifier $1,2 \% / 100 \mathrm{~g}$ berpengaruh nyata $(\mathrm{P}<0,05)$ menurunkan konsumsi pakan serta pertambahan bobot badan, dan berpengaruh nyata meningkatkan konversi pakan $(\mathrm{P}<0,05)$. Kesimpulan dari penelitian ini yaitu stepdown protein $4 \%$ dan $6 \%$ dengan penambahan acidifier 1,2\%/100 gram pakan belum mampu untuk menghasilkan performa terbaik untuk ayam broiler.
\end{abstract}

Kata kunci : ayam broiler, step down protein, acidifier, performans

\section{PENDAHULUAN}

Ayam broiler merupakan unggas yang mampu menghasilkan daging yang baik dan memiliki kelebihan yaitu pertumbuhan yang sangat pesat jika dibandingkan unggas lainnya. Secara genetik, ayam broiler memiliki laju pertumbuhan pesat akan tetapi pertumbuhan tersebut perlu ditunjang dengan kualitas pakan yang baik untuk memenuhi kebutuhan nutrien terutama protein.
Pakan yang diberikan tidak hanya berkualitas namun pemanfaatan pakan harus terjadi didalam pencernaan ayam broiler agar lebih efisien. Penambahan acidifier dapat meningkatkan performa ayam broiler seperti peningkatan kecernaan dan penyerapan protein didalam tubuh ayam broiler. Penurunan level protein (step down protein) dilakukan agar pengeluaran biaya pakan dapat berkurang (Sukamto, 2012). Penurunan level protein dikhawatirkan akan 
menyebabkan kekurangan asupan protein, sehingga dapat berpengaruh terhadap pertumbuhan ayam broiler yang kurang maksimal yang berakibat pada pertambahan bobot badan yang kurang optimal.

Kekhawatiran kurangnya asupan protein perlu solusi penambahan acidifier pada pakan ayam broiler untuk meningkatkan daya cerna dan efisiensi penggunaan pakan agar asupan protein pakan tercukupi sehingga pertumbuhan ayam broiler dapat optimal. Penambahan acidifier dalam pakan bermanfaat dalam meningkatkan kecernaan karena adanya peningkatan aktifitas enzim pada sistem pencernaan sehingga mampu meningkatkan asupan nutrisi pakan dan memperbaiki konversi pakan. Acidifier merupakan asam organik berupa asam sitrat seperti jeruk nipis (asam sitrat alami) maupun asam sitrat sintetik (asam sitrat buatan) yang dapat diberikan atau dicampur dengan pakan maupun dicampur ditempat minum (Hasanuddin et al., 2013).

Menurut penelitian sebelumya Pemberian Pakan Single Step Down 2\% dengan kandungan protein $19 \%$. Penambahan asam sitrat sebesar $(0,8 \%$ asam sitrat, $0,4 \%$, $0,8 \%$ dan $1,2 \%$ air perasan jeruk nipis) sebagai Acidifier terhadap performa pertumbuhan broiler oleh Saputra et al.,
(2013) menunjukkan bahwa penambahan asam sitrat alami dengan konsentrasi 0,4\% dalam pakan single step down mampu menghasilkan performa/pertumbuhan terbaik pada ayam broiler. Berdasarkan uraian diatas maka telah dilakukan penelitian pengaruh step down protein dan penambahan acidifier pada pakan terhadap performans ayam broiler.

Tujuan penelitian ini adalah untuk mengkaji pengaruh pengaruh step down protein dan penambahan acidifier pada pakan terhadap performans ayam broiler. Manfaat dari penelitian ini diharapkan dapat diperoleh informasi mengenai efek penambahan acidifier dan step down protein pakan.

\section{MATERI DAN METODE}

Materi penelitian yang digunakan yaitu ayam broiler sebanyak 210 ekor DOC unsex strain $C o b b$ dengan rata-rata bobot badan $44,34 \pm 0,14$ gram. Pakan penelitian yang digunakan adalah complete feed $\mathrm{S}_{12}$ yang dikombinasikan dengan jagung kuning dan bekatul untuk mendapatkan protein yang sesuai dengan perlakuan. Kandungan nutrisi bahan penyusun pakan seperti tertera pada Tabel 1 .

Tabel 1. Kandungan nutrisi bahan penyusun pakan

\begin{tabular}{ccccccc}
\hline BahanPakan & $\mathrm{EM}^{(*)}$ & $\mathrm{PK}^{(* *)}$ & $\mathrm{LK}^{(* *)}$ & $\mathrm{SK}^{(* *)}$ & $\mathrm{Ca}^{(* *)}$ & $\mathrm{P}^{(* *)}$ \\
\hline S10 & & & $----------\%$ & ----------- & \\
S11 & 3382,17 & 22,97 & 8.00 & 3,26 & 0,97 & 0,72 \\
S12 & 3168,35 & 22,19 & 5,67 & 3,22 & 0,84 & 0,59 \\
JagungKuning & 2515,34 & 22,38 & 7,00 & 3,05 & 0,82 & 0,50 \\
Bekatul & 3540,08 & 9,65 & 4,67 & 2,86 & 0,08 & 0,27 \\
\hline
\end{tabular}

(*) Hasil analisis proksimat di Laboratorium MediaLab PT. Medion Farma Jaya, Semarang

(**) Nilai Energi Metabolis (EM) dihitung berdasarkan rumus Carpenter dan Clegg (Anggorodi, 1994)

$\mathrm{BETN}=100-(\%$ Air $+\%$ Abu $+\% \mathrm{PK}+\% \mathrm{LK}+\% \mathrm{SK})$

$\mathrm{EM}=40,81 \times(0,87 \times(\mathrm{PK}+(2,25 \mathrm{x} \mathrm{LK})+\mathrm{BETN}+2,5)$

Penelitian menggunakan rancangan percobaan rancangan acak lengkap (RAL) dengan 3 perlakuan dan 7 ulangan, keseluruhan terdapat 21 unit percobaan. Pemberian pakan dilakukan secara $a d$ libitum.
Perlakuan acidifier dan step down protein pakan yaitu :

$\mathrm{T}_{0}$ : Pakan dengan protein pakan $22 \%$

$\mathrm{T}_{1}$ : Asam sitrat sintetis $1,2 \% / 100 \mathrm{~g}$ pakan dan protein pakan $18 \%$

$\mathrm{T}_{2}$ : Asam sitrat sintetis $1,2 \% / 100 \mathrm{~g}$ pakan dan protein pakan $16 \%$ 
Parameter yang diamati adalah konsumsi pakan, pertambahan bobot badan (PBB) dan konversi pakan (FCR).

1. Konsumsi pakan dengan cara melakukan perbandingan jumlah pemberian pakan dengan sisa pakan lalu ditimbang. (Saputra et al. 2013)

Konsumsi Pakan $=$

Pakan yang diberikan (g) - Sisa Pakan (g)

Jumlah Ayam (ekor)

2. Laju pertambahan bobot badan diukur dengan cara menghitung bobot badan awal dan bobot badan akhir selama masa pemeliharaan. (Saputra et al. 2013).
PBB = Bobot Akhir $(g)-$ Bobot Awal $(g)$

3. Konversi pakan (FCR) diukur dengan cara perbandingan antara jumlah konsumsi pakan dengan pertambahan bobot badan selama waktu pemeliharaan. (Saputra et al. 2013)

FCR $=\frac{\text { Konsumsi Pakan }(\mathrm{g})}{\text { Pertambahan Bobot Badan (g/ekor) }}$

Data yang diperoleh dianalisis menggunakan prosedur analisis ragam dengan uji $\mathrm{F}$ untuk mengetahui pengaruh perlakuan. Jika hasil analisis menunjukkan pengaruh yang nyata pada taraf signifikan 5\% akan dilanjutkan dengan uji wilayah ganda Duncan.

Tabel 2. Komposisi dan Kandungan Nutrisi Pakan Penelitian

\begin{tabular}{lrrr}
\hline \multirow{2}{*}{ Komposisi Pakan } & \multicolumn{3}{c}{ Perlakuan } \\
\cline { 2 - 4 } \multicolumn{1}{c}{ S $_{12}$} & T0 & T1 & T2 \\
\cline { 2 - 4 }$\quad$ Jagung Kuning & 100 & 69 & 46 \\
$\quad$ Bekatul & 0 & 16 & 27 \\
\multicolumn{1}{c}{ Total } & 0 & 15 & 100 \\
\hline Kandungan Nutrisi & 100 & 100 & \\
Protein Kasar (\%) & & & 16,25 \\
Energi Metabolisme (kkal/kg) & 22,38 & 18,85 & 3271,20 \\
Serat Kasar (\%) & 3314,71 & 3290,87 & 6,03 \\
Lemak Kasar (\%) & 3,05 & 4,70 & 8,44 \\
Kadar Abu (\%) & 7,00 & 7,78 & 5,17 \\
Kadar Air (\%) & 5,67 & 5,35 & 9,17 \\
Kadar Kalsium (\%) & 9,17 & 9,48 & 0,42 \\
Kadar Phospor (\%) & 0,82 & 0,59 & 0,94 \\
\hline
\end{tabular}

*) Hasil analisis proksimat di Laboratorium MediaLab PT. Medion Farma Jaya, Semarang

\section{HASIL DAN PEMBAHASAN}

\section{Konsumsi Pakan}

Konsumsi pakan merupakan jumlah pakan yang terkonsumsi oleh ternak untuk memenuhi kebutuhan hidup pokok dan kebutuhan produksi ternak selama masa pemeliharaan. Hasil penelitian pengaruh step down protein dan penambahan acidifier pada pakan terhadap konsumsi pakan ayam broiler disajikan pada Tabel 2. Hasil analisis ragam menunjukkan bahwa konsumsi pakan berbeda nyata $(\mathrm{P}<0,05)$. 
Tabel 3. Rata-rata konsumsi pakan ayam broiler yang mendapat perlakuan penambahan step down protein pakan dan penambahan acidifier.

\begin{tabular}{|c|c|c|c|}
\hline \multirow{2}{*}{ Ulangan } & \multicolumn{3}{|c|}{ Konsumsi Pakan } \\
\hline & T0 & $\mathrm{T} 1$ & $\mathrm{~T} 2$ \\
\hline & \multicolumn{3}{|c|}{----------------(g/ekor/hari)--------------- } \\
\hline 1 & $3.572,00$ & $3.030,00$ & $3.027,50$ \\
\hline 2 & $3.105,50$ & $3.015,50$ & $3.007,50$ \\
\hline 3 & $3.193,00$ & $3.423,50$ & $2.915,00$ \\
\hline 4 & $3.313,50$ & $3.325,00$ & $3.276,00$ \\
\hline 5 & $3.589,50$ & $3.268,50$ & $3.138,50$ \\
\hline 6 & $3.402,50$ & $3.217,50$ & $3.155,00$ \\
\hline 7 & $3.495,00$ & $3.435,50$ & $3.397,00$ \\
\hline Total & 23671,00 & 22715,50 & 21916,50 \\
\hline Rata - rata & $3.381,57^{\mathrm{a}}$ & $3.245,07^{b}$ & $3.130,93^{\mathrm{c}}$ \\
\hline
\end{tabular}

Superskrip yang berbeda pada baris yang sama menunjukkan berbeda nyata $(\mathrm{P}<0,05)$

Rata-rata konsumsi pakan ayam broiler penelitian selama 35 hari adalah sebesar 3.252,52 g/ekor. Menurut Cobb Vantress (2008), standar konsumsi pakan umur 5 minggu untuk ayam broiler strain Cobb adalah 3016 g/ekor untuk betina dan 3381 g/ekor untuk jantan.

Berdasarkan Tabel 3 menunjukkan nilai konsumsi pakan menurun yaitu pada T0 yang terbesar, diikuti penurunan oleh $\mathrm{T} 1 \mathrm{dan}$ nilai konsumsi terendah adalah $\mathrm{T} 2$. Penurunan konsumsi ayam broiler pada T0 sampai dengan T2 diduga akibat kandungan protein pada perlakuan $18 \%$ dan $16 \%$ dengan penambahan acidifier 1,2\%/100 gram pakan belum mampu untuk mengoptimalisasi konsumsi pakan. Kumar et al. (2016) menyatakan bahwa pengurangan kadar level protein pada pakan dapat menyebabkan penurunan yang signifikan terhadap konsumsi ayam broiler pada fase starter.

Penurunan protein pakan $4 \%$ dan $6 \%$ dengan penambahan acidifier 1,2\%/100 gram pakan belum mampu untuk meningkatkan kecukupan asupan protein. National Research Council (1994) menyatakan bahwa faktorfaktor yang dapat mempengaruhi konsumsi pakan pada ayam broiler adalah kualitas pakan seperti energi metabolis, asupan protein dan imbangan asam amino harus sesuai dengan kebutuhan ternak. Pemberian asam organik (acidifier) kedalam pakan cenderung menurunkan jumlah konsumsi.
Saputra et al. (2013) menyatakan bahwa penambahan asam organik didalam pakan dapat menurunkan palatabilitas sehingga konsumsi berkurang. Menurut Sutrisno et al. (2013) menyatakan bahwa asam sitrat mampu meningkatkan sekresi enzim pencerna protein dan pelepasan hormon seperti gastrin dan kolesistokinin. Gastrin berfungsi sebagai merangsang pelepasan asam lambung dan kolesistokinin berfungsi untuk menstimulasi sekresi kantung empedu.

\section{Pertambahan Bobot Badan}

Pertambahan bobot badan merupakan suatu metode yang digunakan untuk mengukur laju pertumbuhan pada ayam broiler. Pertambahan bobot badan diperoleh dengan melakukan perbandingan bobot akhir yaitu saat panen dan bobot awal selama pemeliharaan. Hasil analisis sidik ragam pertambahan bobot badan menunjukkan bahwa perlakuan pakan step down dengan penambahan acidifier berpengaruh nyata $(\mathrm{P}<0,05)$ menurunkan pertambahan bobot badan. Rata-rata pertambahan bobot badan ayam broiler penelitian yaitu sebesar $1.611,13$ g/ekor. Menurut Cobb Vantress (2008) menyatakan bahwa standar pertambahan bobot badan umur 5 minggu untuk strain Cobb yaitu 1879 gram/ ekor untuk betina dan 2155 gram/ekor untuk jantan. 
Tabel 4. Rata-rata pertambahan bobot badan ayam broiler yang mendapat perlakuan step down protein dan penambahan acidifier pada pakan.

\begin{tabular}{|c|c|c|c|}
\hline \multirow{2}{*}{ Ulangan } & \multicolumn{3}{|c|}{ PBB } \\
\hline & T0 & $\mathrm{T} 1$ & $\mathrm{~T} 2$ \\
\hline & \multicolumn{3}{|c|}{----------------(g/ekor/hari)--------------- } \\
\hline 1 & $1.900,50$ & $1.466,70$ & $1.638,30$ \\
\hline 2 & $1.521,90$ & $1.500,15$ & $1.366,00$ \\
\hline 3 & $1.527,90$ & $1.745,90$ & $1.255,60$ \\
\hline 4 & $1.720,35$ & $1.726,15$ & $1.586,80$ \\
\hline 5 & $1.908,85$ & $1.570,20$ & $1.400,70$ \\
\hline 6 & $1.715,55$ & $1.558,40$ & $1.438,60$ \\
\hline 7 & $1.868,20$ & $1.763,95$ & $1.653,00$ \\
\hline Total & 12163,25 & 11331,45 & 10339,00 \\
\hline Rata - rata & $1.737,61^{\mathrm{a}}$ & $1.618,78^{\mathrm{b}}$ & $1.477,00^{\mathrm{c}}$ \\
\hline
\end{tabular}

Superskrip yang berbeda pada baris yang sama menunjukkan berbeda nyata $(\mathrm{P}<0,05)$

Berdasarkan hasil Tabel 4 menunjukkan bahwa nilai pertambahan bobot badan perlakuan step down protein dengan penambahan acidifier mengalami penurunan diikuti konsumsi pakan yang turun (Tabel 3). Menurut Anggitasari (2016) bahwa pakan yang mengandung protein yang tinggi dapat meningkatkan pertambahan bobot badan yang lebih tinggi. Nuraini (2009) menyatakan bahwa besarnya pertambahan bobot badan ada kaitannya dengan seberapa besar jumlah konsumsi protein yang termakan oleh ayam broiler. Konsumsi protein untuk $\mathrm{T} 0=27,29 ; \mathrm{T} 1=25,31$; dan $\mathrm{T} 2=21,75$, sehingga dengan penurunan konsumsi protein berakibat pada penurunan Pertambahan bobot badan. Hal ini mengindikasikan bahwa penurunan protein pakan $4 \%$ dan $6 \%$ dengan penambahan acidifier sebesar 1,2\% (100 g) belum mampu untuk meningkatkan pertambahan bobot badan. Setiawati et al. (2011) menyatakan bahwa faktor yang dapat mempengaruhi pertambahan bobot badan sangat ditentukan oleh kualitas pakan yaitu kandungan protein dan asam amino seperti lisin dan metionin.

\section{Konversi Pakan}

Konversi pakan (FCR) merupakan perbandingan jumlah konsumsi pakan dengan pertambahan bobot badan. Hasil penelitian tentang konversi pakan ayam broiler dapat dilihat pada Tabel 5.

Tabel 5. Rata-rata konversi pakan ayam broiler yang mendapat perlakuan step down protein dan penambahan acidifier pada pakan

\begin{tabular}{|c|c|c|c|}
\hline \multirow{2}{*}{ Ulangan } & \multicolumn{3}{|c|}{ Konversi Pakan } \\
\hline & T0 & T1 & $\mathrm{T} 2$ \\
\hline & \multicolumn{3}{|c|}{ 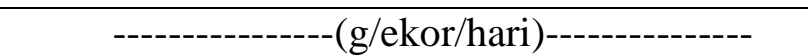 } \\
\hline 1 & 1,88 & 2,07 & 1,85 \\
\hline 2 & 2,04 & 2,01 & 2,20 \\
\hline 3 & 2,09 & 1,96 & 2,32 \\
\hline 4 & 1,93 & 1,93 & 2,06 \\
\hline 5 & 1,88 & 2,08 & 2,24 \\
\hline 6 & 1,98 & 2,06 & 2,19 \\
\hline 7 & 1,87 & 1,95 & 2,06 \\
\hline Total & 13,67 & 14,06 & 14,92 \\
\hline Rata - rata & $1,95^{\mathrm{c}}$ & $2,01^{b}$ & $2,13^{\mathrm{a}}$ \\
\hline
\end{tabular}

Superskrip yang berbeda pada baris yang sama menunjukkan berbeda nyata $(\mathrm{P}<0,05)$ 
Hasil analisis ragam (Tabel 5) menunjukkan bahwa perlakuan stepdown protein pakan dengan penambahan acidifier berpengaruh berbeda nyata $((\mathrm{P}<0,05)$ meningkatkan konversi pakan. Berdasarkan Tabel 5 menunjukkan bahwa nilai konversi pakan perlakuan step down protein dengan penambahan acidifier mengalami peningkatan. Konversi pakan yang tinggi diduga disebabkan akibat dari penurunan level protein, konsumsi yang turun (Tabel 3), disertai dengan penurunan pertambahan bobot badan (Tabel 4).

Kamran et al. (2008) melaporkan bahwa peningkatan konsumsi dapat terjadi karena penurunan kadar protein sementara bobot badan yang dihasilkan juga ikut menurun yang menyebabkan nilai konversi pakan cenderung tinggi. Tabel 3 memperlihatkan bahwa step down protein 4\% dan $6 \%$ dengan penambahan acidifier belum mampu meningkatkan konsumsi pakan yang berakibat menurunkan pertambahan bobot badan sehingga konversi pakan meningkat. Hal ini mengindikasikan bahwa penurunan level protein pakan $4 \%$ dan $6 \%$ dengan penambahan acidifier $1,2 \% / 100 \mathrm{~g}$ pakan belum mampu untuk mengoptimalkan nilai konversi pakan.

Menurut Wahju (2004) bahwa rendahnya nilai konversi pakan artinya untuk menghasilkan satu kilogram daging pakan yang dibutuhkan akan semakin sedikit. Saepulmillah (2010) menyatakan bahwa semakin tinggi angka nilai konversi pakan maka semakin banyak pula pakan yang dibutuhkan untuk meningkatkan bobot badan. Triawan et al. (2013) menyatakan bahwa faktor yang dapat mempengaruhi konversi pakan adalah kualitas pakan, jenis pakan, dan penambahan zat aditif. Hasanuddin et al. (2013) menyatakan bahwa Acidifier (asam organik) berfungsi untuk meningkatkan kecernaan didalam tubuh dengan cara peningkatan kinerja enzim pencernaan, sehingga menyebakan sensasi asam yang menurunkan $\mathrm{pH}$ dalam usus untuk menjaga keseimbangan mikrobia disaluran pencernaan dan dapat menekan bakteri patogen yang menyebabkan usus menjadi sehat.

\section{KESIMPULAN}

Kesimpulan dari penelitian ini step down protein $4 \%$ dan $6 \%$ dengan penambahan acidifier 1,2\% /100 gram pakan belum mampu untuk meningkatkan performa ayam broiler.

\section{DAFTAR PUSTAKA}

Anggitasari, S., O. Sjofjan dan I. H. Djunaidi. 2016. Pengaruh beberapa jenis pakan komersial terhadap kinerja produksi kuantitatif dan kualitatif ayam pedaging. J. Buletin Peternakan. 40 (3): 187-196.

Cobbvantress. 2008. Broiler performance and nutrition supplement. Cobb 500. Cobb- Vantress Inc., Arkansas

Hasanuddin. S. V. D. 2013. Lemak dan kolesterol daging pada ayam broiler yang diberi pakan step down protein dengan penambahan Air perasan jeruk nipissebagai acidifier. Buletin Nutrisi dan Makanan Ternak. 9 (1) : 47-53.

Kamran, Z., M. Sarwar, M. Nisa, M. A. Nadeem, S. Mahmood, M. E. Babar and S. Ahmed. 2008. Effect of low protein diets having constant energy to protein ratio on performance and carcass characteristics of broiler chickens from one to thirtyfive days of age. J. Poultry Science. 87 : 468474.

Kumar, C. B., R. G. Gloridoss., K. C. Singh., T. M. Prabhu, and B. N. Suresh. 2016. Performance of broiler chickens fed low protein, limiting amino acid supplemented diets formulated either on total or standardized ileal digestible amino acid basis. J. Animal Sci. 29(11): $1616-1624$. 
National Research Council. 1994. Nutrient Requirements of Poultry. $9^{\text {th }}$ resived edition. National Academic Press, Wasington, DC.

Nuraini. 2009. Performa broiler dengan ransum mengandung campuran ampas sagu dan ampas tahu yang difermentasikan dengan Neurospora crasa. Media Peternakan. 32 (3) :196203.

Saepulmillah, A. 2010. Performa Performa Ayam Broiler yang Diberi Pakan Komersial dan Pakan Nabati dengan Penambahan Dysapro. Departemen Ilmu Produksi dan Teknologi Peternakan Fakultas Peternakan Institut Pertanian Bogor, Bogor. (Skripsi).

Saputra, W. Y., N. Suthama dan L. D. Mahfudz. 2013. Pemberian kombinasi pakan double step down dan asam sitrat sebagai upaya peningkatan efisiensi usaha peternakan broiler. J. Buletin Nutrisi dan Makanan Ternak. 10 (1) : 34-40.

Sukamto, B. 2012. Kebutuhan Energi dan Protein Ransum Unggas. Badan Penerbit Universitas Diponegoro, Semarang.

Sutrisno., V. D. Yunianto dan N. Suthama. 2013. Kecernaan protein kasar dan pertumbuhan broiler yang diberi pakan single step down dengan penambahan acidifier asam sitrat. J. Animal Agriculture. 2 (3): 48-60.

Triawan, A., D. Sudrajat dan Anggraeni. 2013. Performa ayam broiler yang diberi ransum mengandung neraca kation anion ransum yang berbeda. J. Pertanian. 4 (2) : 73-81.

Wahju, J. 2004. Ilmu Nutrisi Unggas. Edisi kelima. Gadjah Mada Press, Yogyakarta. 